\title{
Diet of Southern Toads (Bufo terrestris) in Loblolly Pine (Pinus taeda) Stands Subject to Coarse Woody Debris Manipulations
}

\author{
KURTIS R. MOSELEY ${ }^{1}$ AND STEVEN B. CASTLEBERRY \\ D.B. Warnell School of Forest Resources, University of Georgia, Athens 30602 \\ JAMES L. HANULA \\ USDA Forest Service, Forestry Sciences Laboratory, 320 Green Street, Athens, Georgia 30602 \\ AND \\ W. MARK FORD \\ USDA Forest Service, Northeastern Research Station, Parsons, West Virginia 26287
}

\begin{abstract}
In the southeastern United States, coarse woody debris (CWD) typically harbors high densities of invertebrates. However, its importance as a foraging substrate for southeastern amphibians is relatively unknown. We examined effects of CWD manipulations on diet composition of southern toads (Bufo terrestris) in upland loblolly pine (Pinus taeda) stands in the Coastal Plain of South Carolina. Twelve 9.3-ha plots were assigned one of the following treatments: removal- all CWD $\geq 10 \mathrm{~cm}$ in diameter and $\geq 60 \mathrm{~cm}$ long removed; downed-five-fold increase in volume of down CWD; and unmanipulated control stands. We collected southern toads $\geq 4 \mathrm{~cm}$ snout-vent length (SVL) during $14 \mathrm{~d}$ sampling periods in June and October 2002, June 2003 and during a 28 d sampling period in April 2003. We collected 80,36 and 35 southern toads in control, downed and removal treatments, respectively. We found no difference in relative abundance or frequency of invertebrate groups consumed among treatments $(\mathrm{P}>0.05)$. Average body weight $(\mathrm{g})$, SVL $(\mathrm{cm})$ and stomach content weight ( $\mathrm{g}$ wet) of individuals also were similar among treatments $(\mathrm{P}>0.05)$. The role of CWD as a foraging substrate for southern toads in loblolly pine stands of the southeastern Coastal Plain may be negligible, at least in the early stages of decay.
\end{abstract}

\section{INTRODUCTION}

Coarse woody debris (CWD) often harbors high densities of invertebrates in terrestrial habitats (Graham, 1925; Savely, 1939; Harmon et al., 1986; Hanula, 1996; Lockaby et al., 2002). Coarse woody debris also offers added protection from predation and dry ambient conditions during foraging periods by terrestrial insectivorous vertebrate species (Loeb, 1996; Whiles and Grubaugh, 1996). These characteristics are believed to make CWD ideal foraging sites for forest dwelling amphibians (Maser et al., 1979). Although use of CWD by southeastern amphibians has been documented (Whiles and Grubaugh, 1996), its importance as a foraging substrate in the region remains unknown.

The southern toad is an abundant species throughout the Coastal Plain of the southeastern United States. Southern toads, and other species of Bufo, feed predominately on ants (Formicidae) and beetles (Coleoptera; Bush and Menhinick, 1962; Brown, 1974; Clarke, 1974a; Punzo, 1992; Bellocq et al., 2000). For example, stomach contents of southern toads collected in Florida were composed primarily of beetles (19-31\%) and ants (12-18\%),

\footnotetext{
${ }^{1}$ Corresponding author present address: West Virginia University, Division of Forestry, Box 6125, Morgantown 26506; Telephone: (706)338-5413; FAX: (706)542-8356; e-mail: kmoseley@mix.wvu.edu
} 
with spiders (Araneae; 8-11\%) and unidentified insects (22-35\%) comprising the remainder (Punzo, 1992). Stomach contents of Fowler's toads (B. woodhousei fowleri) collected in agricultural fields and nearby hardwood forests in the Coastal Plain of Arkansas were limited almost entirely to ground-dwelling insects such as ants and beetles (Brown, 1974). Diet of American toads (B. americanus), Great Plains toads (B. cognatus), plateau toads (B. compactilis) and Woodhouse's toads ( $B$. woodhouseii woodhousii) in Oklahoma consisted primarily of different types of beetles and ants (Smith and Bragg, 1949). Bellocq et al. (2000) speculated that microclimate variation associated with different forest stand structural characteristics influenced insect assemblages and, therefore, affected food resource availability for insectivorous vertebrate species.

In a broad ecological sense, CWD is an important component of forest stand structure (Hunter, 1990; McComb and Lindenmayer, 1999). Many invertebrate groups associated with decomposing woody material are negatively affected by CWD volume reductions (Harmon et al., 1986; Lattin, 1993; Freedman et al., 1996; McCay et al., 2002). Abundance of ground beetles (Carabidae) and silken fungus beetles (Cryptophagidae) declined $1 \mathrm{y}$ after removal of downed CWD in upland loblolly pine stands in the Coastal Plain of South Carolina (McCay et al., 2002). As predators dependent on invertebrates in forested ecosystems, species of Bufo may be heavily affected by fluctuations in invertebrate abundance caused by reductions in CWD volume.

We investigated effects of CWD manipulations in upland loblolly pine stands on diet composition of southern toads. We hypothesized that southern toads captured in plots subject to CWD removal would consume a lower diversity and abundance of prey items. Furthermore, we hypothesized that fewer foraging opportunities, because of reductions in cover from predators and inadequate availability of moist refugia, would result in lower stomach content and body weight.

\section{Study Area ANd Methods}

Our study was conducted at the Savannah River Site (SRS), a 78,000-ha National Environmental Research Park located in the Upper Coastal Plain physiographic region in an area known as the Sandhills in Aiken, Barnwell and Allendale counties, South Carolina $\left(33^{\circ} 0-25^{\prime \prime} \mathrm{N}, 81^{\circ} 25-50^{\prime \prime} \mathrm{W}\right)$. Upland areas were dominated by the longleaf pine (Pinus palustris)-wiregrass (Aristida spp.) community before being cleared for agriculture in the early 1800s. The Atomic Energy Commission acquired the land comprising the SRS in 1951 and the USDA Forest Service was contracted to plant abandoned agricultural fields in loblolly, longleaf and slash pine $(P$. elliottii). Currently, pine plantations dominate most of the SRS landscape. The regional climate is warm temperate to subtropical with a mean annual temperature of $18 \mathrm{C}$ and mean annual precipitation of $122.5 \mathrm{~cm}$.

Experimental stands were selected based on the following criteria: forested with loblolly pine approximately $45-50 \mathrm{y}$ in age, capable of accommodating four square 9.3 -ha plots and located $\geq 76 \mathrm{~m}$ from the nearest wetland, road or power line. Four square 9.3-ha plots were established within stands, each containing a 6-ha core area to be used for southern toad and invertebrate sampling surrounded by a 3.3-ha buffer area subject to the same treatment. Dominant understory vegetation consisted of lespedeza (Lespedeza spp.), poison oak (Toxicodendron pubescens), beggarweed (Desmodium spp.) and broomsedge (Andropogon spp.).

Plots within each stand were randomly assigned to one of three treatments: removal- all downed woody debris $\geq 10 \mathrm{~cm}$ in diameter and $\geq 60 \mathrm{~cm}$ long removed $(\mathrm{n}=3)$, downed- 5 -fold increase in volume of down CWD $(n=3)$ and unmanipulated control $(n=6)$. A private crew under USFS supervision removed all downed woody material by hand during summer 1996 
and each winter 1997-2003. Downed treatments were implemented in August 2001 by randomly selecting 12 rows of trees to be felled within plots using a feller-buncher. Trees were not moved subsequent to felling. Our manipulations were not intended to mimic natural CWD dynamics and because sampling began shortly after trees were downed, all CWD additions occupied the earliest stages of decay. Additionally, effects of below ground CWD, such as decomposing tree stumps, were beyond the scope of our study. Control and removal plots were subsequently thinned to standardize basal area among treatments. Trees felled within these plots as a result of thinning were subsequently removed. Estimates of mean ( \pm $\mathrm{SE}$ ) coarse woody debris loadings were $56.2 \pm 6.6,4.5 \pm 1.0$ and $2.4 \pm 1.0 \mathrm{~m}^{3} /$ ha in downed, control and removal plots, respectively. Most plots were prescribed burned between 1990 and 1996 in accordance with normal land management practices for forests at the SRS.

We sampled southern toads using a series of drift fence arrays. Drift fences were made from aluminum flashing buried $15 \mathrm{~cm}$ in the ground. Nineteen plastic buckets were buried against each fence, flush to the ground. On each plot, a centrally located cross-shaped array with $30 \mathrm{~m}$ arms was installed. In each corner of the center array, Y-shaped arrays with $15 \mathrm{~m}$ arms were installed (Corn, 1994). We opened traps for 14-d periods during June and October 2002 and June 2003. Additionally, we opened traps for a 28 d period during April 2003. We checked traps daily between 0600 and $1200 \mathrm{~h}$. Because we were interested in adult southern toads, we only collected individuals $\geq 4 \mathrm{~cm}$ snout-vent length. We collected a maximum of five toads per sampling period to minimize any effects caused by removal of adult toads. We euthanised individuals via double pithing (McDiarmid, 1994; AVMA Panel on Euthanasia, 2001) within $6 \mathrm{~h}$ of collection and then froze them for later dissection. We collected all individuals under South Carolina Department of Natural Resources scientific research permit \# G-02-09 and University of Georgia IACUC number A2002-10019-c2.

We sampled terrestrial arthropods using 15 pitfall traps placed throughout each plot. We opened traps for $7 \mathrm{~d}$ periods in May, July, September and November 2002, and January and March 2003. At the end of each collection period, we stored arthropods in $70 \%$ ethanol for later analysis. We identified arthropods to order or class and in the case of ants, to family (Formicidae). We calculated relative abundance of arthropod groups for each plot by dividing total number of individuals within each group by the total number of invertebrates captured within that plot.

We weighed $(\mathrm{g})$ individual southern toads, recorded SVL $(\mathrm{cm})$ and then removed the stomach contents which we weighed ( $\mathrm{g}$ wet) and examined for prey. We did not record body weight or stomach content weight of individuals captured during the June 2002 sampling period. Invertebrates found within stomach contents were identified to order or class and, in the case of ants, to family. We identified invertebrates primarily through presence of head capsules to prevent counting a single individual twice. We calculated relative abundance as described above for invertebrate groups consumed. We defined frequency of occurrence as percent of stomachs from each treatment plot containing at least one individual of a given prey group.

We treated individual toads as subsamples within replicates to test for CWD treatment effects. Diet composition did not differ between sexes $(\mathrm{P}>0.05)$, so we pooled them for analysis. We tested data for normality using a Shapiro-Wilks test, ranked variables that did not meet assumptions of normality, even after transformation, and performed analysis on the ranks. We used a two-way analysis of variance (ANOVA) to test for differences in relative abundance of invertebrate groups consumed, frequency of occurrence of each invertebrate group consumed and mean number of prey items identified in stomach contents among control, removal and downed treatments. We standardized body weight and stomach content weight by individual SVL and tested for differences in body weight, stomach content weight 
TABLE 1.-Mean ( $\pm \mathrm{SE}$ ) relative abundance of prey items in stomach contents of southern toads (Bufo terrestris) captured in June and October 2002 and April and June 2003 at the Savannah River Site, Barnwell County, South Carolina, in loblolly pine (Pinus taeda) stands subject to addition of downed coarse woody debris (CWD), removal of CWD and controls. Relative abundance of each group was compared among treatments with a 2-way Analysis of Variance

\begin{tabular}{lccccc}
\hline \hline & Downed $(\mathrm{n}=3)$ & Removal $(\mathrm{n}=3)$ & Control $(\mathrm{n}=6)$ & $\mathrm{F}_{2,7}$ & $\mathrm{P}$ \\
\hline Formicidae & $0.622 \pm 0.004$ & $0.731 \pm 0.034$ & $0.611 \pm 0.058$ & 1.84 & 0.228 \\
Coleoptera & $0.170 \pm 0.030$ & $0.158 \pm 0.023$ & $0.216 \pm 0.028$ & 1.30 & 0.330 \\
Araneae & $0.064 \pm 0.013$ & $0.022 \pm 0.007$ & $0.060 \pm 0.017$ & 1.79 & 0.236 \\
Hymenoptera $^{1,2}$ & $0.038 \pm 0.011$ & $0.012 \pm 0.004$ & $0.041 \pm 0.020$ & 1.21 & 0.353 \\
Orthoptera $^{1}$ & $0.026 \pm 0.010$ & $0.045 \pm 0.012$ & $0.037 \pm 0.015$ & 0.63 & 0.562 \\
Immatures $^{1}$ & $0.024 \pm 0.018$ & $0.008 \pm 0.005$ & $0.008 \pm 0.004$ & 0.17 & 0.844 \\
Blattaria $^{1}$ & $0.017 \pm 0.004$ & $0.002 \pm 0.002$ & $0.005 \pm 0.003$ & 3.63 & 0.083 \\
Chilopoda $^{1}$ & $0.013 \pm 0.009$ & $0.003 \pm 0.003$ & $0.007 \pm 0.005$ & 0.66 & 0.548 \\
Gastropoda $^{1}$ & $0.013 \pm 0.006$ & $0.007 \pm 0.004$ & $0.003 \pm 0.002$ & 1.39 & 0.310 \\
Isoptera $^{1}$ & $0.003 \pm 0.003$ & $0.002 \pm 0.002$ & $0 \pm 0$ & 1.01 & 0.412 \\
Diptera $^{1}$ & $0.002 \pm 0.002$ & $0.002 \pm 0.002$ & $002 \pm 0.001$ & 0.02 & 0.979 \\
Diplopoda $^{1}$ & $0 \pm 0$ & $0.002 \pm 0.002$ & $0.006 \pm 0.004$ & 0.57 & 0.588 \\
Homoptera $^{1}$ & $0 \pm 0$ & $0.005 \pm 0.005$ & $0.006 \pm 0.005$ & 0.60 & 0.575 \\
\hline
\end{tabular}

${ }^{1}$ ANOVA performed on ranks

${ }^{2}$ Excluding Formicidae

and SVL among treatments using a two-way ANOVA. We analyzed differences among invertebrate abundance and relative abundance of invertebrates captured within plots among treatments with a two-way ANOVA. All statistical analyses were conducted using SAS statistical software (SAS Institute, 1997).

Diet similarity among treatments was compared using Morisita's index of dietary overlap (Litvaitus et al., 1996), which produces values between 0 and 1, where 0 indicates no overlap in diet and 1 indicates total overlap. This index $(\mathrm{C})$ is considered the least biased diet overlap estimator (Smith and Zaret, 1982). However, because we only identified most prey items to order, our results should be interpreted cautiously as similarity between treatments may be overestimated (Greene and Jaksic, 1983).

\section{RESUlTS}

We collected 80, 36 and 35 southern toads in control, downed and removal treatments, respectively. Southern toad stomach contents consisted of 13 invertebrate groups with ants being the most abundant (Table 1) and most frequently consumed (Table 2) prey item among all three treatments, followed by beetles and spiders (Araneae). We found no differences in relative abundance (Table 1) or frequency (Table 2) of the 13 invertebrate groups consumed among treatments. Mean number of prey items found in stomachs was $9.97 \pm 1.64,11.07 \pm 1.14$ and $11.92 \pm 1.61$ in control, downed and removal plots, respectively. Number of prey items in stomach contents did not differ among treatments $\left(\mathrm{F}_{2,7}=\right.$ $0.52, \mathrm{P}=0.618$ ).

We captured representatives of 18 terrestrial arthropod groups across all treatments. Arthropod groups captured in plots were similar in both numbers captured (Table 3) and relative capture rate (Table 4) among treatments. Combined abundance of captured arthropods in the 13 groups identified in stomach contents did not differ among treatments $\left(\mathrm{F}_{2,7}=0.69, \mathrm{P}=0.535\right)$. 
TABLE 2.- Mean ( \pm SE) frequency of occurrence of prey items identified in stomach contents of southern toads (Bufo terrestris) captured in June and October 2002 and April and June 2003 at the Savannah River Site, Barnwell County, South Carolina, in loblolly pine (Pinus taeda) stands subject to addition of downed coarse woody debris (CWD), removal of CWD and controls. Relative abundance of each group was compared among treatments with a 2-way Analysis of Variance

\begin{tabular}{|c|c|c|c|c|c|}
\hline & Downed $(\mathrm{n}=3)$ & Removal $(\mathrm{n}=3)$ & Control $(\mathrm{n}=6)$ & $\mathrm{F}_{2,7}$ & $\mathrm{P}$ \\
\hline Formicidae & $87.08 \pm 2.39$ & $74.44 \pm 2.94$ & $80.60 \pm 3.00$ & 2.50 & 0.152 \\
\hline Coleoptera & $78.08 \pm 1.03$ & $65.56 \pm 9.88$ & $74.95 \pm 6.64$ & 1.03 & 0.404 \\
\hline Araneae & $34.84 \pm 3.31$ & $23.33 \pm 8.82$ & $25.95 \pm 4.68$ & 0.84 & 0.472 \\
\hline Hymenoptera $^{1,2}$ & $18.58 \pm 4.31$ & $15.56 \pm 7.29$ & $17.45 \pm 8.24$ & 0.42 & 0.670 \\
\hline Orthoptera & $26.41 \pm 10.44$ & $33.33 \pm 3.33$ & $23.47 \pm 5.22$ & 0.58 & 0.585 \\
\hline Immatures $^{1}$ & $7.63 \pm 3.82$ & $5.56 \pm 2.94$ & $7.93 \pm 3.76$ & 0.16 & 0.857 \\
\hline Blattaria & $12.70 \pm 4.91$ & $3.33 \pm 3.33$ & $5.37 \pm 2.17$ & 1.52 & 0.282 \\
\hline Chilopoda $^{1}$ & $10.37 \pm 5.79$ & $2.22 \pm 2.22$ & $5.52 \pm 2.86$ & 0.64 & 0.556 \\
\hline Gastropoda $^{1}$ & $12.55 \pm 6.31$ & $7.78 \pm 4.01$ & $3.27 \pm 2.18$ & 1.39 & 0.310 \\
\hline Isoptera $^{1}$ & $3.70 \pm 3.70$ & $3.33 \pm 3.33$ & $0 \pm 0$ & 1.01 & 0.412 \\
\hline Diptera $^{1}$ & $1.96 \pm 1.96$ & $3.33 \pm 3.33$ & $2.99 \pm 1.38$ & 0.29 & 0.757 \\
\hline Diplopoda $^{1}$ & $0 \pm 0$ & $3.33 \pm 3.33$ & $3.57 \pm 2.44$ & 0.54 & 0.606 \\
\hline Homoptera $^{1}$ & $0 \pm 0$ & $4.44 \pm 4.44$ & $3.42 \pm 2.40$ & 0.60 & 0.575 \\
\hline
\end{tabular}

\footnotetext{
${ }^{1}$ ANOVA performed on ranks

${ }^{2}$ Excluding Formicidae
}

Mean weight of individual southern toads $(\mathrm{g} / \mathrm{cm})$ was $3.41 \pm 0.09,3.57 \pm 0.06$ and $3.32 \pm$ 0.16 in control, downed and removal plots, respectively. Weight did not differ among treatments $\left(\mathrm{F}_{2,7}=1.35, \mathrm{P}=0.320\right)$. Mean stomach content weight $(\mathrm{g} / \mathrm{cm})$ of individuals was $0.12 \pm 0.02,0.13 \pm 0.02$ and $0.12 \pm 0.02$ in control, downed and removal plots, respectively, and did not differ among treatments $\left(\mathrm{F}_{2,7}=0.11, \mathrm{P}=0.900\right)$. Mean SVL $(\mathrm{cm})$ of individuals in control, downed and removal plots was $5.50 \pm 0.06,5.44 \pm 0.06$ and $5.39 \pm 0.02$, respectively, and did not differ among treatments $\left(\mathrm{F}_{2,7}=0.80, \mathrm{P}=0.487\right)$.

We found a high degree of dietary overlap among treatments, with downed and removal treatments being the most similar $(\mathrm{C}=0.99)$, followed by downed and control $(\mathrm{C}=0.98)$ and removal and control $(\mathrm{C}=0.97)$. Individuals captured in removal plots contained the highest number of prey groups $(n=13)$ followed by control $(n=12)$ and downed $(n=11)$ plots.

Because relative abundance of invertebrates consumed and relative capture rate of invertebrates within plots did not differ among treatments, for all southern toads, we combined treatments to compare consumption of invertebrate groups with their occurrence in plots using a one-way ANOVA (Fig. 1). Variables did not meet assumptions of normality. We rank transformed all variables except spiders and ants and performed analysis on the ranks. Ants $\left(\mathrm{F}_{1,20}=60.85, \mathrm{P}<0.0001\right)$, beetles $\left(\mathrm{F}_{1,20}=14.74, \mathrm{P}=0.001\right)$ and true bugs (Homoptera) $\left(\mathrm{F}_{1,20}=5.73, \mathrm{P}=0.027\right)$ were consumed in greater proportion to their relative capture rate, whereas spiders $\left(\mathrm{F}_{1,20}=73.14, \mathrm{P}<0.0001\right)$, flies (Diptera) $\left(\mathrm{F}_{1,20}=100.32\right.$, $\mathrm{P}<0.0001)$ and millipedes (Diplopoda) $\left(\mathrm{F}_{1,20}=60.42, \mathrm{P}<0.0001\right)$ were consumed proportionately less than their relative capture rate in plots (Fig. 1).

\section{Discussion}

Although CWD has been identified as an important foraging substrate for amphibians in the southeast (Whiles and Grubaugh, 1996), our results indicate that southern toads may not depend on CWD in early decay stages for invertebrate prey in upland pine stands of the 
TABLE 3.-Mean ( \pm SE) captures of arthropod groups in plots subject to downed coarse woody debris (CWD) additions, CWD removal and controls in upland loblolly pine (Pinus taeda) stands at the Savannah River Site, Barnwell County, South Carolina, during May, July, September and November 2002 and January and March 2003. Relative abundance of each group was compared among treatments with a two-way analysis of variance

\begin{tabular}{|c|c|c|c|c|c|}
\hline & Downed $(\mathrm{n}=3)$ & Removal $(\mathrm{n}=3)$ & Control $(\mathrm{n}=6)$ & $\mathrm{F}_{2,7}$ & $\mathrm{P}$ \\
\hline Formicidae & $1683 \pm 168$ & $1427 \pm 183$ & $1483 \pm 182$ & 0.33 & 0.729 \\
\hline Araneae & $714 \pm 78$ & $649 \pm 90$ & $805 \pm 53$ & 1.95 & 0.212 \\
\hline Diptera & $570 \pm 154$ & $497 \pm 160$ & $564 \pm 117$ & 0.10 & 0.905 \\
\hline Coleoptera & $429 \pm 86$ & $464 \pm 33$ & $531 \pm 54$ & 1.89 & 0.221 \\
\hline Orthoptera & $223 \pm 24$ & $161 \pm 53$ & $183 \pm 24$ & 0.78 & 0.496 \\
\hline Hymenoptera $^{2}$ & $208 \pm 63$ & $134 \pm 26$ & $176 \pm 27$ & 0.99 & 0.419 \\
\hline Diplopoda & $130 \pm 25$ & $192 \pm 29$ & $154 \pm 42$ & 0.54 & 0.604 \\
\hline Immatures & $73 \pm 25$ & $49 \pm 10$ & $61 \pm 8$ & 0.69 & 0.534 \\
\hline Hemiptera & $32 \pm 3$ & $26 \pm 7$ & $39 \pm 4$ & 3.81 & 0.076 \\
\hline Phalangida & $31 \pm 12$ & $25 \pm 10$ & $34 \pm 6$ & 0.19 & 0.832 \\
\hline Blattaria & $27 \pm 1$ & $26 \pm 8$ & $39 \pm 4$ & 2.41 & 0.160 \\
\hline Chilopoda & $31 \pm 10$ & $30 \pm 2$ & $34 \pm 4$ & 0.33 & 0.729 \\
\hline Homoptera & $15 \pm 2$ & $11 \pm 0$ & $16 \pm 2$ & 1.86 & 0.225 \\
\hline Lepidoptera & $10 \pm 2$ & $7 \pm 3$ & $14 \pm 1$ & 3.85 & 0.075 \\
\hline Thysanura ${ }^{1}$ & $14 \pm 12$ & $8 \pm 7$ & $12 \pm 7$ & 0.46 & 0.648 \\
\hline Chelonethida & $7 \pm 2$ & $5 \pm 2$ & $6 \pm 3$ & 0.15 & 0.863 \\
\hline Psocoptera $^{1}$ & $7 \pm 5$ & $4 \pm 1$ & $19 \pm 8$ & 1.11 & 0.381 \\
\hline Isoptera ${ }^{1}$ & $6 \pm 6$ & $13 \pm 7$ & $5 \pm 4$ & 1.55 & 0.277 \\
\hline
\end{tabular}

${ }^{1}$ ANOVA performed on ranks

${ }^{2}$ Excluding Formicidae

southeastern Coastal Plain. The only obligatory CWD invertebrate group identified in stomach contents was termites. Termites were consumed infrequently by southern toads in our study, being identified in less than $4 \%$ of all stomachs and consumed in proportion to their relative capture rate on plots. Termites represented $7-11 \%$ of prey items consumed by southern toads captured in the Coastal Plain of Florida during Spring, but decreased (3-5\%) for individuals captured during Summer (Punzo, 1992). Conversely, stomach contents of southern toads collected along roadsides within Everglades National Park did not contain any termites (Krakauer, 1968). Because they are more digestible than invertebrates with more chitinous exoskeletons, such as ants and beetles (Dimmitt and Rubal, 1980), termites may be underrepresented in stomach content samples. Termites found in fecal matter collected from common Malayan toads (Bufo melanostictus) were almost completely digested, identifiable only by presence of head capsules. Conversely, ant exoskeletons were frequently found intact, having undergone little digestion (Berry and Bullock, 1962).

In our study consumption of roaches (Blattaria), a common inhabitant of standing and downed coarse woody material (Horn and Hanula, 2002), was 8.5 times greater in downed than in control treatments. However, because they were consumed proportional to their relative capture rate (Fig. 1) and constituted a minor component of all prey items identified (Table 1), increased consumption may only reflect opportunistic use of CWD. Ants and beetles comprised the majority of prey items in our study, which combined, accounted for 79.2, 88.9 and $82.7 \%$ of stomach contents in downed, removal and control treatments, respectively.

We found no difference in relative abundance or frequency of invertebrate groups consumed among treatments. Similar diet composition observed among treatments may be 
TABLE 4.-Mean ( $\pm \mathrm{SE}$ ) relative capture rate of arthropod groups captured in plots subject to downed coarse woody debris (CWD) additions, CWD removal and controls in upland loblolly pine (Pinus taeda) at the Savannah River Site, Barnwell County, South Carolina, during May, July, September and November 2002 and January and March 2003. Relative abundance of each group was compared among treatments with a two-way analysis of variance

\begin{tabular}{llllll}
\hline \hline & Downed $(\mathrm{n}=3)$ & Removal $(\mathrm{n}=3)$ & Control $(\mathrm{n}=6)$ & $\mathrm{F}_{2,7}$ & $\mathrm{P}$ \\
\hline Formicidae & $0.404 \pm 0.030$ & $0.385 \pm 0.048$ & $0.357 \pm 0.042$ & 0.36 & 0.710 \\
Araneae & $0.170 \pm 0.008$ & $0.173 \pm 0.013$ & $0.194 \pm 0.013$ & 1.10 & 0.383 \\
Diptera & $0.131 \pm 0.020$ & $0.129 \pm 0.030$ & $0.133 \pm 0.025$ & 0.01 & 0.992 \\
Coleoptera & $0.102 \pm 0.016$ & $0.128 \pm 0.018$ & $0.013 \pm 0.006$ & 2.21 & 0.180 \\
Orthoptera $^{2}$ & $0.054 \pm 0.005$ & $0.042 \pm 0.010$ & $0.044 \pm 0.005$ & 0.61 & 0.569 \\
Hymenoptera $^{2}$ & $0.047 \pm 0.009$ & $0.037 \pm 0.010$ & $0.043 \pm 0.007$ & 0.32 & 0.735 \\
Diplopoda & $0.031 \pm 0.006$ & $0.051 \pm 0.003$ & $0.037 \pm 0.010$ & 0.98 & 0.421 \\
Immatures $_{\text {Hemiptera }}$ & $0.018 \pm 0.007$ & $0.013 \pm 0.002$ & $0.015 \pm 0.002$ & 0.65 & 0.551 \\
Phalangida & $0.008 \pm 0$ & $0.007 \pm 0.001$ & $0.009 \pm 0.001$ & 3.35 & 0.095 \\
Blattaria & $0.008 \pm 0.004$ & $0.007 \pm 0.003$ & $0.008 \pm 0.002$ & 0.02 & 0.979 \\
Chilopoda & $0.007 \pm 0.001$ & $0.007 \pm 0.002$ & $0.009 \pm 0.001$ & 1.17 & 0.365 \\
Homoptera & $0.007 \pm 0.001$ & $0.008 \pm 0$ & $0.008 \pm 0.001$ & 0.99 & 0.419 \\
Lepidoptera & $0.004 \pm 0$ & $0.003 \pm 0$ & $0.004 \pm 0$ & 0.94 & 0.435 \\
Thysanura $^{1}$ & $0.003 \pm 0.001$ & $0.002 \pm 0.001$ & $0.004 \pm 0$ & 2.82 & 0.127 \\
Chelonethida & $0.003 \pm 0.002$ & $0.002 \pm 0.002$ & $0.003 \pm 0.001$ & 0.24 & 0.794 \\
Psocoptera $^{1}$ & $0.002 \pm 0$ & $0.001 \pm 0.001$ & $0.001 \pm 0.001$ & 0.11 & 0.894 \\
Isoptera $^{1}$ & $0.002 \pm 0.001$ & $0.001 \pm 0$ & $0.004 \pm 0.002$ & 1.19 & 0.360 \\
\hline
\end{tabular}

${ }^{1}$ ANOVA performed on ranks

${ }^{2}$ Excluding Formicidae

attributable to lack of response by preferred invertebrate groups, such as ants and beetles, to CWD manipulations. Abundance of certain invertebrate groups can be negatively affected by CWD removal (Harmon et al., 1986; Lattin, 1993; Freedman et al., 1996; McCay et al., 2002; Bouget and Duelli, 2004). However, abundance of ants and beetles remained similar among treatment types despite a $56.2 \mathrm{~m}^{3} /$ ha increase or removal of downed woody material. Ants and beetles are abundant in southeastern pine forests (Hanula and Franzreb, 1998; Hanula and Wade, 2003). Sanzone (1995) found abundance of Coleopterans and Hymenopterans captured in a loblolly pine stand on the Coastal Plain of South Carolina was lower in pitfall traps associated with CWD than in traps independent of downed pine logs. Additionally, ant abundance adjacent to partially decomposed CWD was greater than near recently felled CWD.

The lack of treatment responses by arthropods in our study may be related in part to the early decay stage of the recently downed CWD. As wood decays, composition of the invertebrate community in the logs will change (Graham, 1925; Savely, 1939; Elton, 1966), but whether CWD in more advanced stages of decay will affect composition of ground dwelling invertebrate assemblages, and thus diet composition of southern toads, is unclear.

We found no difference in body weight and stomach content weight of southern toads or mean number of prey items consumed among our treatments, indicating that individuals were able to effectively forage following removal of CWD. Despite greater CWD inputs in recently harvested stands, body weight of southern toads in $19 \mathrm{y}$ old intensively managed loblolly pine stands was similar to individuals in recently clearcut loblolly pine stands in the Coastal Plain of South Carolina (Baughman, 2000). Studies investigating effects of forest 


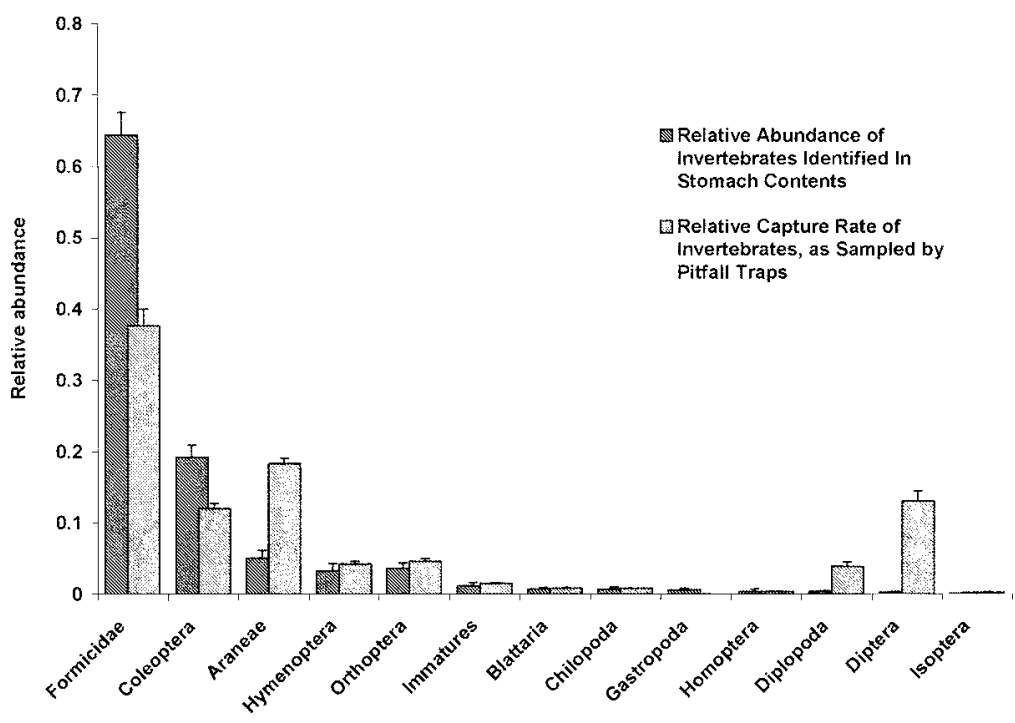

FIG. 1.-Mean ( $\pm \mathrm{SE}$ ) relative abundance of invertebrates consumed by southern toads (Bufo terrestris) vs. mean relative capture rate of invertebrates captured in plots subject to downed coarse woody debris (CWD) additions, CWD removal and controls in upland loblolly pine (Pinus taeda) at the Savannah River Site, Barnwell County, South Carolina, during May, July, September and November 2002 and January and March 2003

management practices, such as timber harvesting and subsequent site preparation, in the Coastal Plain region of the United States have found these practices to have relatively little affect on abundance and diversity of many terrestrial invertebrates in the near-term, at least at higher taxonomic levels (Greenberg and Thomas, 1995; Greenberg and McGrane, 1996; Bird et al., 2000). Abundance and biomass of ground-dwelling arthropods in sand pine (Pinus clausa) scrub in Ocala National Forest, Florida did not differ in stands subjected to intense burning and salvage logging, clearcutting followed by roller-chopping, clearcutting followed by bracke seeding and naturally regenerated mature stands, despite lower woody debris in roller-chopped and mature stands in terms of density, diversity and evenness of beetles (Greenberg and Thomas, 1995; Greenberg and McGrane, 1996). Clarke (1974a) suggested that food is rarely a limiting factor during the terrestrial stage of Bufo species and that availability of moisture in the terrestrial environment may be more limiting.

Historically, upland areas of the southeastern Coastal Plain were dominated by the longleaf pine-wiregrass community, which was maintained by frequent, low intensity, ground fires that occurred during the growing season (Landers et al., 1995; Frost, 1998; Van Lear and Harlow, 2002). Frequent fires, combined with greater decomposition rates, probably prevented buildup of CWD within upland pine stands (Van Lear, 1996). Indeed, pine forests of the Southeast generally have a lower abundance of CWD than forests of the Pacific Northwest or Appalachian regions (McMinn and Hardt, 1996). Properties of CWD that would benefit Bufo species as a moist microhabitat are probably only achieved after advanced stages of decomposition and greater water holding ability develops (Boddy, 1983). However, because of high decomposition rates and frequent fires in upland pine systems, CWD occupying advanced decay classes is probably sparse and short-lived. As a foraging substrate, CWD may be less important than leaf litter and exposed forest floor, where Bufo species often forage on 
nights with acceptable levels of ambient moisture and temperature (Klimstra and Myers, 1964; Clarke, 1974b; Gibbons and Bennett, 1974). Because our addition treatments were limited to recently felled CWD, future studies should focus on CWD in more advanced stages of decay.

Acknowledgments.-We thank S. Horn and P. Champlin for field assistance. We also thank J. Kilgo, K. Miller and two anonymous reviewers for helpful comments on this manuscript. We are grateful to the U.S. Department of Energy for access to the Savannah River Site. Funding for this project was provided by the U. S. Department of Energy-Savannah River Operations Office through the U. S. Forest Service-Savannah River and the USFS Northeast Research Station under Interagency Agreement DE-AI09-00SR22188.

\section{Literature Cited}

AVMA Panel on Euthanasia. 2001. 2000 report of the AVMA panel on euthanasia. J. Am. Vet. Med. Assoc., 218:669-696.

Baughman, W. M. 2000. The effects of corridors on herpetofauna assemblages in intensively managed forests. Ph.D. Dissertation, Clemson Univ., Clemson, South Carolina 68 p.

Belloce, M. I., K. Kloosterman and S. M. Smith. 2000. The diet of coexisting species of amphibians in Canadian jack pine forests. Herpet. J., 10:63-68.

BerRY, P. Y. AND J. A. Bullock. 1962. The food of the common Malayan toad, Bufo melanostictus Schneider. Copeia, 1962:736-741.

Bird, S., R. N. Coulson And D. A. Crossley, Jr. 2000. Impacts of silvicultural practices on soil and litter arthropod diversity in a Texas pine plantation. For. Ecol. Manage., 131:65-80.

BodDy, L. 1983. Microclimate and moisture dynamics of wood decomposing in terrestrial ecosystems. Soil Biol. and Biochem., 15:149-157.

Bouget, C. AND P. Duelui. 2004. The effects of windthrows on forest insect communities: a literature review. Biol. Cons., 118:281-299.

Brown, R. L. 1974. Diets and habitat preferences of selected anurans in southeast Arkansas. Am. Midl. Nat., 91:468-473.

Bush, F. M. And E. F. Menhinick. 1962. The food of Bufo woodhousei fowleri Hinckley. Herpetologica, 18: $110-114$.

Clarke, R. D. 1974a. Food habits of toads, Genus Bufo (Amphibia: Bufonidae). Am. Midl. Nat., 91: $140-147$.

- 1974b. Activity and movement patterns in a population of Fowler's toad, Bufo woodhousei fowleri. Am. Midl. Nat., 92:257-274.

ConN, P. S. 1994. Straight line drift fences and pitfall traps, p. 109-117. In: W. R. Heyer, M. A. Donnelly, R. W. McDiarmid, L. C. Hayek and M. S. Foster (eds.). Measuring and monitoring biological diversity: standard methods for amphibians. Smithsonian Institute Press, Washington, D.C. 364 p.

Dimmitt, M. A. and R. Ruibal. 1980. Exploitation of food resources by spadefoot toads (Scaphiopus). Copeia, 1980:854-862.

Elton, C. S. 1966. The pattern of animal communities. John Wiley and Sons, New York. 305 p.

Freedman, B., V. Zelazny, D. Beaudette, T. Fleming, S. Flemming, G. Forbes, J. S. Gerrow, G. Johnson and S. WOODLEY. 1996. Biodiversity implications of changes in the quantity of dead organic matter in managed forests. Environ. Rev., 4:238-265.

Frost, C. C. 1998. Presettlement fire frequency regimes of the United States: a first approximation, p. 70-81. In: T. L. Pruden and L. A. Brennan (eds.). Fire in ecosystem management: shifting the paradigm from suppression to prescription: Proc. $20^{\text {th }}$ Tall Timbers Fire Ecol. Conf. 1996. Tallahassee, Florida.

GibBons, J. W. And D. H. Bennett. 1974. Determination of anuran terrestrial activity patterns by a drift fence method. Copeia, 1974:236-243.

Graham, S. A. 1925. The felled tree trunk as an ecological unit. Ecology, 6:397-412.

GreEne, H. W. AND F. M. JAKSIC. 1983. Food-niche relationships among sympatric predators: effects of level of prey identification. Oikos, 40:151-154. 
Greenberg, C. H. And M. C. Thomas. 1995. Effects of forest management practices on terrestrial coleopteran assemblages in sand pine scrub. Fla. Entom., 78:271-285.

AND A. McGrane. 1996. A comparison of relative abundance and biomass of ground-dwelling arthropods under different forest management practices. For. Ecol. Manage., 89:31-41.

Hanula, J. L. 1996. Relationship of wood-feeding insects and coarse woody debris, p. 55-81. In: J. W. McMinn and D. A. Crossley, Jr. (eds.). Biodiversity of coarse woody debris in Southern Forests. Proc. Work. Coarse Woody Debris in Southern Forests: Effects on Biodiversity. U.S. For. Serv., Gen. Tech. Rep. SE-94. 146 p.

AND K. FranzREb. 1998. Source, distribution and abundance of macroarthropods on the bark of longleaf pine: potential prey of the red-cockaded woodpecker. For. Ecol. Manage., 102:89-102. AND D. D. WADE. 2003. Influence of long-term dormant-season burning and fire exclusion on ground-dwelling arthropod populations in longleaf pine flatwoods ecosystems. For. Ecol. Manage., 175:163-184.

Harmon, M. E., J. F. Franklin, F. J. Swanson, P. Sollins, S. V. Gregory, J. D. Lattin, N. Cromack, Jr. and K. W. Cummins. 1986. Ecology of coarse woody debris in temperate ecosystems. Adv. Ecol. Res., 15:133-302.

Horn, G. S. AND J. L. HANula. 2002. Life history and habitat associations of the broad wood cockroach, Parcoblatta lata (Blattaria: Blattellidae) and other native cockroaches in the Coastal Plain of South Carolina. Ann. Entomol. Soc. Am., 95:665-671.

Hunter, M. L., JR. 1990. Wildlife, forests and forestry. Prentice Hall, Englewood Cliffs, New Jersey. 370 p.

Kuimstra, W. D. And C. W. Myers. 1964. Food of the toad, Bufo woodhousei Fowleri Hinckley. Trans. Ill. Acad. Sci., 58:11-26.

Krakauer, T. 1968. The ecology of the neotropical frog, Bufo marinus, in south Florida. Herpetologica, 24:214-221.

LANders, J. L., D. H. VAn Lear And W. D. Boyer. 1995. The longleaf pine forests of the southeast: requiem or renaissance. J. Forestry, 93:39-44.

LatTin, J. D. 1993. Arthropod diversity and conservation in old-growth northwest forests. Am. Zool., 33:578-587.

Litvaitus, J. A., K. Titus and E. M. Anderson. 1996. Measuring vertebrate use of terrestrial habitats and food, p. 254-274. In: T. A. Bookout (ed.). Research and management techniques for wildlife and habitats, 5th ed. The Wildlife Society, Bethesda, Maryland. $740 \mathrm{p}$.

Lockaby, B. G., B. D. Keeland, J. A. Stanturf, M. D. Rice, G. Hodges and R. M. Governo. 2002. Arthropods in decomposing wood of the Atchafalaya river basin. Southeastern Nat., 1:339-352.

LOEB, S. C. 1996. The role of coarse woody debris in the ecology of southeastern Mammals, p. 108-118. In: J. W. McMinn and D. A. Crossley, Jr. (eds.). Biodiversity of coarse woody debris in Southern Forests: effects on Biodiversity. Proc. Work. Coarse Woody Debris in Southern Forests. U.S. For. Serv., Gen. Tech. Rep. SE-94. 146 p.

Maser, C., R. G. Anderson, K. Cromack, JR., J. T. Williams and R. E. Martin. 1979. Dead and down woody material, p. 78-90. In: J. W. Thomas (ed.). Wildlife habitat in managed forests-the Blue Mountains of Oregon and Washington. U.S. For. Serv., Agri. Handbook 553.

McCay, T. S., J. L. Hanula, S. C. Loeb, S. M. Lohr, J. W. McMinn and B. D. Wright-Miley. 2002. The role of coarse woody debris in southeastern pine forests: preliminary results from a large-scale experiment, p. 135-144. In: W. F. Laudenslayer, Jr., P. J. Shea, B. E. Valentine, C. P. Weatherspoon and T. E. Lisle (eds.). Proc. Symp. the Ecology and Management of Dead Wood in Western Forests. U.S. For. Serv., Gen. Tech. Rep. PSW-181. 949 p.

McComb, W. and D. Lindenmayer. 1999. Dying, dead and down trees, p. 335-372. In: M. L. Hunter, Jr. (ed.). Maintaining biodiversity in forest ecosystems. Cambridge University Press, New York. 698 p.

McDiarmid, R. W. 1994. Preparing amphibians as scientific specimens, p. 289-297. In: W. R. Heyer, M. A. Donnelly, R. W. McDiarmid, L. C. Hayek and M. S. Foster (eds.). Measuring and monitoring biological diversity: standard methods for amphibians. Smithsonian Institute Press, Washington, D.C. 364 p.

McMinn, J. W. And R. A. Hardt. 1996. Accumulation of coarse woody debris in southern forests, p. 1-9. In: J. W. McMinn and D. A. Crossley, Jr. (eds.). Biodiversity of coarse woody debris in Southern 
Forests. Proc. Work. Coarse Woody Debris in Southern Forests: Effects on Biodiversity. U.S. For. Serv., Gen. Tech. Rep. SE-94. 146 p.

Punzo, F. 1992. Dietary overlap and activity patterns in sympatric populations of Scaphiopus holbrookii (Pelobatidae) and Bufo terrestris (Bufonidae). Fla. Sci., 55:38-44.

SANzone, D. M. 1995. Macroarthropods associated with coarse woody debris: factors influencing abundance and diversity patterns. M.Sc. Thesis, University of Georgia, Athens. 112 p.

SAS INSTITUTE. 1997. SAS/STAT software: changes and enhancements through release 6. 12. SAS Institute, Cary, North Carolina.

SAvely, H. E. 1939. Ecological relations of certain animals in dead pine and oak logs. Ecol. Monogr., 9:322-377.

Smith, C. C. ANd A. N. BRAGG. 1949. Observations on the ecology and natural history of Anura, VII. Food and feeding habits of the common species of toads in Oklahoma. Ecology, 30:333-349.

Smith, E. P. And T. M. Zaret. 1982. Bias in estimating niche overlap. Ecology, 63:1248-1253.

VAN LEAR, D. H. 1996. Dynamics of coarse woody debris in southern forest ecosystems, p. 10-17. In: J.W. McMinn and D.A. Crossley, Jr. (eds.). Biodiversity of coarse woody debris in Southern Forests: effects on biodiversity. Proc. Work. Coarse Woody Debris in Southern Forests. U.S. For. Serv., Gen. Tech. Rep. SE-94. 146 p.

- AND R. F. HaRlow. 2002. Fire in the eastern United States: influence on wildlife habitat, p. 2-10. In: W. M. Ford, K. R. Russell and C. E. Moorman (eds.). The role of fire in nongame wildlife management and communitiy restoration: traditional uses and new directions proceedings of a special workshop. U.S. For. Serv., Gen. Tech. Rep. NE-288. 145 p.

Whiles, M. R. and J. W. Grubaugh. 1996. Importance of coarse woody debris to southern forest herpetofauna, p. 94-100. In: J. W. McMinn and D. A. Crossley, Jr. (eds.). Biodiversity of coarse woody debris in Southern Forests: effects on biodiversity. Proc. Work. Coarse Woody Debris in Southern Forests. U.S. For. Serv., Gen. Tech. Rep. SE-94. 146 p. 